\title{
MICROBIAL COMMUNITY COMPOSITION AND FUNCTION ACROSS AN ARCTIC TUNDRA LANDSCAPE
}

\author{
Donald R. ZAK ${ }^{1,2,3}$ AND GeORGe W. KLinG ${ }^{2}$ \\ ${ }^{1}$ School of Natural Resources and Environment, University of Michigan, Ann Arbor, Michigan 48109-1115 USA \\ ${ }^{2}$ Department of Ecology and Evolutionary Biology, University of Michigan, Ann Arbor, Michigan 48109-1048 USA
}

\begin{abstract}
Arctic landscapes are characterized by a diversity of ecosystems, which differ in plant species composition, litter biochemistry, and biogeochemical cycling rates. Tundra ecosystems differing in plant composition should contain compositionally and functionally distinct microbial communities that differentially transform dissolved organic matter as it moves downslope from dry, upland to wet, lowland tundra. To test this idea, we studied soil microbial communities in upland tussock, stream-side birch-willow, and lakeside wet sedge tundra in arctic Alaska, USA. These are a series of ecosystems that differ in topographic position, plant composition, and soil drainage. Phospholipid fatty acid (PLFA) analyses, coupled with compound-specific ${ }^{13} \mathrm{C}$ isotope tracing, were used to quantify microbial community composition and function; we also assayed the activity of extracellular enzymes involved in cellulose, chitin, and lignin degradation. Surface soil from each tundra ecosystem was labeled with ${ }^{13} \mathrm{C}$ cellobiose, ${ }^{13} \mathrm{C}-N$-acetylglucosamine, or ${ }^{13} \mathrm{C}$-vanillin. After a five-day incubation, we followed the movement of ${ }^{13} \mathrm{C}$ into bacterial and fungal PLFAs, microbial respiration, dissolved organic carbon, and soil organic matter. Microbial community composition and function were distinct among tundra ecosystems, with tussock tundra containing a significantly greater abundance and activity of soil fungi. Although the majority of ${ }^{13} \mathrm{C}$-labeled substrates rapidly moved into soil organic matter in all tundra soils (i.e., $50-90 \%$ of applied ${ }^{13} \mathrm{C}$ ), microbial respiration of labeled substrates in wet sedge tundra soil was lower than in tussock and birch-willow tundra; $\sim 8 \%$ of ${ }^{13} \mathrm{C}$-cellobiose and $\sim 5 \%$ of ${ }^{13} \mathrm{C}$-vanillin was respired in wet sedge soil vs. $26-38 \%$ of ${ }^{13} \mathrm{C}$ cellobiose and $18-21 \%$ of ${ }^{13} \mathrm{C}$-vanillin in the other tundra ecosystems. Despite these differences, wet sedge tundra exhibited the greatest extracellular enzyme activity. Topographic variation in plant litter biochemistry and soil drainage shape the metabolic capability of soil microbial communities, which, in turn, influence the chemical composition of dissolved organic matter across the arctic tundra landscape.
\end{abstract}

Key words: arctic tundra; ${ }^{13} \mathrm{C}$ tracers; dissolved organic carbon; extracellular enzymes; landscape patterns; microbial communities.

\section{INTRODUCTION}

Although microbial communities mediate key biogeochemical processes in soil, it is uncertain whether microbial community composition varies in a predictable manner with landscape-level patterns of soil organic matter transformation (Myers et al. 2001, McCulley and Burke 2004, Stevenson et al. 2004). One hypothesis is that consistent topographic changes from upland landscape positions to those downslope constrain plant community characteristics, which in turn influence the composition and function of soil microbial communities. For example, in arctic Alaska, USA, the biogeochemical cycling of carbon (C) dramatically changes across topographic gradients from uplands dominated by tussock tundra to wet sedge tundra lying downslope (Giblin et al. 1991, Nadelhoffer et al. 1991, Cheng et al.

Manuscript received 24 August 2005; revised 13 January 2006; accepted 16 January 2006. Corresponding Editor: R. W. Ruess.

${ }^{3}$ E-mail: drzak@umich.edu
1998). These spatial patterns of $\mathrm{C}$ cycling are, in part, controlled by heterotrophic microbial communities in soil, whose activity is more responsive to differences in plant litter biochemistry among tundra ecosystems than to soil temperature (Nadelhoffer et al. 1991, Hobbie 1996, Cheng et al. 1998). Because organic substrates in plant litter largely structure soil microbial communities, these observations present the possibility that floristically distinct tundra ecosystems also differ in the composition and function of underlying soil microbial communities. However, it is unclear how this plantmicrobe linkage is modified or constrained by topography and the resulting patterns of soil drainage in arctic landscapes. Do spatial patterns of microbial community composition and function parallel environmental gradients that structure landscape-level patterns of plant community composition and biogeochemical processes? Links between plant and microbial communities have been established in alpine ecosystems (Lipson et al. 1999, 2002, Schadt et al. 2003); however, this relationship remains largely unexplored in the arctic 
tundra, and it could have important implications for understanding soil organic matter transformations as well as the biogeochemical cycling of $\mathrm{C}$ across arctic landscapes.

Determining the relationship between microbial communities, rates of $\mathrm{C}$ cycling, and downslope patterns of ecosystems requires an understanding of the physical and biogeochemical linkages across the landscape. As soils seasonally thaw across the tundra, different ecosystems become physically connected by the subsurface flow of water (Shaver et al. 1991). Dissolved organic carbon (DOC) transported below ground via subsurface flow is biochemically transformed as it passes through a series of functionally distinct tundra ecosystems as it travels downslope toward streams and lakes (Shaver et al. 1991, Kling et al. 2000). Landscape-level transport of DOC is an important link between terrestrial and aquatic ecosystems, and export of DOC from arctic tundra can be a substantial percentage of net primary productivity ( $37 \%$; Judd and Kling 2002). This linkage makes microbial transformation along the flow path an important factor influencing the amount and type of DOC entering aquatic ecosystems (Kling et al. 2000) because DOC production and transformation can vary substantially among different ecosystems on the arctic landscape (Judd and Kling 2002). For example, DOC production in tussock- and shrub-dominated tundra is substantially greater than in wet sedge tundra that lies downslope (Judd and Kling 2002, Neff and Hooper 2002); however, soluble phenolics compose a larger portion of DOC in wet sedge tundra relative to ecosystems upslope (Michaelson et al. 1998). Taken together, these observations suggest that DOC differs biochemically among tundra ecosystems, or that microbial communities beneath them (in the soil of these ecosystems) are functionally different, or both. Although DOC is produced and processed as it moves from one tundra ecosystem to another, it is uncertain whether microbial communities along this path differ in their physiological capacity to metabolize labile and recalcitrant forms of DOC.

Our objectives were to determine (1) whether soil microbial communities differ in composition and function among floristically and edaphically distinct arctic tundra ecosystems, (2) if components of DOC are metabolized differently by microbial communities beneath these ecosystems, and (3) whether such differences influence the flow of $\mathrm{C}$ through microbial communities into soil organic matter. To address our objectives, we used a molecular approach (phospholipid fatty acid [PLFA] analysis) to quantify microbial community composition in three common tundra ecosystems in arctic Alaska, USA. We also used ${ }^{13}$ C-labeled compounds to follow the flow of common and representative organic substrates into soil bacteria, actinomycetes, and fungi as well as into microbial respiration and soil organic matter. We gained additional insight into microbial community function and pathways of $\mathrm{C}$ flow using laboratory assays of microbial respiration, net methane production, and the activity of extracellular enzymes involved in the degradation of plant (cellulose and lignin) and fungal (chitin) litter.

\section{Methods \\ Study sites and field sampling}

We studied microbial community composition and function beneath three floristically distinct tundra ecosystems that commonly occur across the north slope of the Brooks Range in northern Alaska, USA (Britton 1966, Shaver et al. 1991). These ecosystems are named for their dominant plant species; they are the tussock, birch-willow, and wet sedge tundra. Tussock tundra covers a wide geographic extent, and it is dominated by Eriophroum vaginatum (a tussock-forming sedge) and codominated by a range of other graminoids, evergreen and deciduous shrubs, and bryophytes (Shaver and Chapin 1991). Despite occurring in upland landscape positions, soils beneath tussock tundra are poorly drained owing to a low slope gradient, shallow thaw depth $(\sim 40 \mathrm{~cm})$, and limited hydraulic conductivity. Birch-willow occurs as strips along water-track and stream margins in moist tundra uplands to where they enter lowland wetlands or lakes. Dominant plants in the birch-willow ecosystem are Betula nana, Salix glauca, and $S$. pulchra. Wet sedge tundra is dominated by Carex aquatilis, Eriophorum angustifolium, and other rhizomatous sedges; it occurs in areas that are inundated with water draining from upslope ecosystems for most or all of the growing season. Soils in wet sedge tundra thaw to a greater depth $(\sim 1 \mathrm{~m})$ than those upslope, and they are characterized by long periods of anoxia. These three ecosystems repeatedly occur across the arctic landscape, with tussock tundra giving way to birch-willow or wet sedge, depending on local hydrologic conditions.

In August 2003, two sites in each ecosystem type were chosen to provide spatial replication of each ecosystem across the landscape. All sites were located at the Toolik Lake Long-Term Ecological Research (LTER) site on the Alaskan northslope $\left(68^{\circ} 38^{\prime} \mathrm{N}, 149^{\circ} 34^{\prime} \mathrm{W}\right.$; elevation $760 \mathrm{~m}$ ); our study sites were positioned adjacent to the main terrestrial LTER plots just south of Toolik Lake. The tussock and birch-willow sites were located on the Itkillik I glacial surface, whereas the wet sedge sites were on the Itkillik II glacial surface. Tussock tundra and wet sedge sites were $\sim 1$ ha in size, within which we randomly located four sampling points to collect surface soil. Soil sampling in birch-willow sites also occurred in a $\sim 1$-ha area, which was oriented as narrow bands (5-10 m wide) paralleling two separate first-order streams. At each sampling point, we collected a soil core $7.5 \mathrm{~cm}$ in diameter and $\sim 20 \mathrm{~cm}$ in depth. The four soil cores collected within each site were composited in the field and transported to the field laboratory for the addition of ${ }^{13} \mathrm{C}$-labeled substrates. Soil temperature (at 5-10 cm depth) at the time of sampling was $\sim 2.5^{\circ} \mathrm{C}$, with no 
measurement exceeding $4^{\circ} \mathrm{C}$ at any location. Permafrost had thawed to a seasonal maximum depth at the time of our soil sampling (August). This condition allowed surface soil to freely drain in the tussock tundra, whereas it remained somewhat saturated in the birchwillow tundra; the wet sedge tundra had several centimeters of standing water above the soil surface. Surface soil horizons (Oe and $\mathrm{Oa}$ ) were organic matter rich (100-400 $\mathrm{mg} \mathrm{C} / \mathrm{g})$ in all ecosystems, with $\mathrm{pH}(0.01$ $\mathrm{mol} / \mathrm{L} \mathrm{CaCl} 2)$ measurements in a narrow range among tussock $(3.8 \pm 0.09$ [mean $\pm \mathrm{sE}])$, birch-willow $(4.1 \pm$ $0.08)$, and wet sedge $(4.5 \pm 0.05)$ tundra (we obtained these data from the Ecosystems Center at the Marine Biological Laboratory, Woods Hole, Massachusetts, USA; available online). ${ }^{4}$

\section{Microbial metabolism of ${ }^{13} \mathrm{C}$-labeled compounds in tundra soils}

Composite soil samples were homogenized and the majority of visible coarse and fine roots were removed by hand. From each composite sample, we removed six 40 -g subsamples ( $20 \mathrm{~g}$ dry mass), which were placed into individual Mason jars. We added ${ }^{13} \mathrm{C}$-cellobiose to two subsamples, ${ }^{13} \mathrm{C}-N$-acetylglucosamine to another two, and the remaining two received ${ }^{13} \mathrm{C}$-vanillin. Thus, we added each ${ }^{13} \mathrm{C}$-labeled substrate to two replicate soil subsamples from each site; the average of these analytical replicates was used in all of our statistical analyses. Vanillin and $\mathrm{N}$-acetylglucosamine were universally labeled compounds, whereas each cellobiose molecule contained one ${ }^{13} \mathrm{C}$ atom. We used these compounds because they are soluble products of cellulose, chitin, and lignin degradation, making them sources of dissolved organic matter that can be transported and transformed by microbial communities across the arctic landscape. The labeled compounds were dissolved in deionized water and delivered to each soil subsample in a 5-mL volume. We applied $282.9 \mu \mathrm{g} / \mathrm{g}$ soil of ${ }^{13} \mathrm{C}$-cellobiose, $32.9 \mu \mathrm{g} / \mathrm{g}$ of ${ }^{13} \mathrm{C}-\mathrm{N}$-acetylglucosamine, and $22.9 \mu \mathrm{g} / \mathrm{g}$ of ${ }^{13} \mathrm{C}$-vanillin to the $40-\mathrm{g}$ subsamples from each site. After isotope addition, we repeatedly mixed each labeled soil subsample to ensure that ${ }^{13} \mathrm{C}$ compounds were distributed as evenly as possible. Mason jars containing soil from the wet sedge ecosystem were purged with $\mathrm{N}_{2}$ to reproduce anaerobic field conditions. Each Mason jar was sealed with an airtight lid that contained a septum for gas sampling; jars were incubated for $5 \mathrm{~d}$ in the dark at field temperature $\left(2.8^{\circ} \mathrm{C}\right)$. Additionally, we incubated unlabeled soil from each site to determine the natural abundance of ${ }^{13} \mathrm{C}$ in microbial and soil pools.

Following the 5-d incubation, we removed $20 \mathrm{~mL}$ of headspace gas and stored it in an evacuated $10-\mathrm{mL}$ vial for analysis of ${ }^{13} \mathrm{CO}_{2}$. To assess rates of microbial respiration and net methane production, an additional

\footnotetext{
${ }^{4}\langle$ http://ecosystems.mbl.edu/arc/data_doc/terrest/ terrestrialdefault.htm $\rangle$
}

4-mL gas sample was removed, and $\mathrm{CO}_{2}$ and $\mathrm{CH}_{4}$ concentrations were immediately analyzed via gas chromatography. After the removal of gas samples, the entire content of each Mason jar was placed in a polyethylene bag, and the sealed bag was stored at $-80^{\circ} \mathrm{C}$. The frozen soil samples were placed on dry ice and transported overnight to the University of Michigan, Ann Arbor, Michigan, USA for further analysis; gas samples were transported under ambient conditions.

\section{Movement of ${ }^{13}$ C-labeled compounds in tundra soils}

We followed the movement of each ${ }^{13} \mathrm{C}$-labeled compound into microbial respiration, microbial phospholipid fatty acids (PLFAs), DOC, and soil organic matter. The $\delta^{13} \mathrm{C}$ of the $\mathrm{CO}_{2}$ produced via microbial respiration was determined using a Finnigan Delta Plus isotope ratio mass spectrometer (IRMS; Thermo Finnigan, San Jose, California, USA). Frozen soil was thawed and $10 \mathrm{~g}$ were lyophilized for PLFA analysis. From a second $10-\mathrm{g}$ subsample of thawed soil, we immediately extracted DOC using $80 \mathrm{~mL}$ of deionized water. The resulting soil-deionized water slurry was vacuum filtered (Millipore, Bedford, Massachusetts, USA) to separate soil and DOC. Soil remaining on the filter was dried at $60^{\circ} \mathrm{C}$ and ground for isotopic analysis of soil organic matter. The concentration and $\delta^{13} \mathrm{C}$ of soil organic $\mathrm{C}$ was determined using an NC2500 elemental analyzer (CE Elantech, Lakewood, New Jersey, USA) interfaced to a Finnigan Delta Plus IRMS. Filtrate containing extracted DOC was passed through a $0.45-\mu \mathrm{m}$ filter, and the concentration and $\delta^{13} \mathrm{C}$ of DOC was determined at the C. C. Hatch Stable Isotope Laboratory (University of Ottawa, Ottawa, Canada) on an OI Analytical 1010 TIC-TOC Analyzer (College Station, Texas, USA) interfaced to a Finnigan Delta Plus IRMS (St-Jean 2003).

Phospholipid fatty acids were extracted from lyophilized soil (1 g) using a single-phase, phosphate-buffered $\mathrm{CHCl}_{3}-\mathrm{CH}_{3} \mathrm{OH}$ solvent system (White et al. 1979). Neutral and glycolipids were separated from PLFAs using silicic acid chromatography, and the phospholipid fatty acid fraction was transesterified using methanolic $\mathrm{KOH}$. The resulting fatty acid methyl esters (FAMEs) were separated and identified using an HP 5973 capillary gas chromatograph. Following chromatographic separation, FAMEs flowed into a combustion interface and the $\mathrm{CO}_{2}$ produced from each entered a Finnigan Delta Plus IRMS (Phillips et al. 2004). This approach enabled us to separate and identify each FAME, as well as determine its concentration and $\delta^{13} \mathrm{C}$.

We report recovery of isotope in microbial respiration, microbial biomass (total PLFA), DOC, and soil organic $\mathrm{C}$ as the percentage of total ${ }^{13} \mathrm{C}$ applied as ${ }^{13} \mathrm{C}$ cellobiose, ${ }^{13} \mathrm{C}$ - $N$-acetylglucosamine, or ${ }^{13} \mathrm{C}$-vanillin in each incubation, accounting for the natural abundance of ${ }^{13} \mathrm{C}$ in each pool. The amount of ${ }^{13} \mathrm{C}$ in soil organic $\mathrm{C}$ was calculated as the difference between total ${ }^{13} \mathrm{C}$ 
recovered in soil and the combined amounts in DOC and total PLFA. To compare the flow of ${ }^{13} \mathrm{C}$ compounds through the microbial food web, we calculated the relative recovery of ${ }^{13} \mathrm{C}$ [i.e., $100 \times$ (amount of ${ }^{13} \mathrm{C}$ in an individual PLFA $/{ }^{13} \mathrm{C}$ in all PLFAs)] in each bacterial, actinomycetal, and fungal PLFA.

\section{Extracellular enzyme activity}

We measured extracellular enzyme activity to assay microbial community function and the potential for cellulose (cellobiohydrolase), chitin ( $N$-acetylglucosaminidase), and lignin (phenol oxidase and peroxidase) degradation in tundra soil. Soil suspensions for enzyme assays were prepared by adding $125 \mathrm{~mL}$ of $50-\mathrm{mmol} / \mathrm{L}$ sodium acetate buffer ( $\mathrm{pH}$ 5.0) to $0.5 \mathrm{~g}$ of soil. The soilbuffer mixture was homogenized using a Brinkman Polytron (Brinkman, Westbury, New York, USA), and the resulting suspension was continually mixed using a stir plate. Fluorometric assays were used to measure the activity of cellobiohydrolase and $N$-acetylglucosaminidase. We used 4-methylumbelliferyl $\beta$-D-cellobiooside (MUB- $\beta \mathrm{G}, 200 \mu \mathrm{mol} / \mathrm{L}$ ) as the substrate for cellobiohydrolase assays, whereas $N$-acetylglucosaminidase was assayed using 4-methylumbelliferyl $N$-acetyl $\beta$-D-glucosaminide as the substrate. Soil suspensions $(200 \mu \mathrm{L})$ were dispensed into 16 replicate assay wells on black 96well microtiter plates (Nalege International, Rochester, New York, USA). We used an additional eight wells as blanks, eight wells to determine sample quenching, and eight wells as controls (i.e., substrate but no soil). Assay wells received $50 \mu \mathrm{L}$ of MUB-linked substrate, whereas blanks received the same volume of acetate buffer. Quench controls received $50 \mu \mathrm{L}$ of MUB $(10-\mu \mathrm{mol} / \mathrm{L} 4-$ methylumbelliferone), and we added $200 \mu \mathrm{L}$ of acetate buffer and $50 \mu \mathrm{L}$ of MUB-linked substrate to the substrate-control wells. The microtiter plates were incubated at $20^{\circ} \mathrm{C}$ for $8 \mathrm{~h}$ in the ambient atmosphere, after which $10 \mu \mathrm{L}$ of $0.5 \mathrm{~mol} / \mathrm{L} \mathrm{NaOH}$ was added to stop the reaction. A Molecular Devices $f$ MAX fluorometer (Sunnyvale, California, USA; excitation $=365$ $\mathrm{nm}$; emission $=460 \mathrm{~nm}$ ) was then used to quantify hydrolysis of MUB-linked substrates during the 8-h incubation.

Phenol oxidase and peroxidase are key mediators of lignin and polyphenol oxidation in soil, and we assayed their activity using L-3,4-dihydroxyphenylalanine (LDOPA $10 \mathrm{mmol} / \mathrm{L}$ ) as a model substrate. These colorimetric assays were conducted in clear 96-well microtiter plates, and they included the same number of replicate assays, blanks, substrate controls, and quench controls as previously described. Peroxidase assays received $10 \mu \mathrm{L}$ of $0.3 \% \mathrm{H}_{2} \mathrm{O}_{2}$. The clear 96-well plates were incubated for $8 \mathrm{~h}$ in the ambient atmosphere (i.e., $\mathrm{O}_{2}$ present) at $20^{\circ} \mathrm{C}$, after which color development was read $(460 \mathrm{~nm}$ ) using a Molecular Devices VERSAmax plate reader. All enzyme activities were reported as nanomoles per gram per hour.

\section{Statistical analyses}

We used a two-way ANOVA to determine the extent to which microbial communities in the three tundra ecosystems differentially metabolized (i.e., percentage recovery) the three ${ }^{13} \mathrm{C}$ substrates. In this model, tundra ecosystems $(n=3)$ were crossed with substrates $(n=3)$; sites $(n=2)$ were considered replicates of each ecosystem. For each site, we averaged analytical replicates for each labeled substrate, and these mean values were used in all statistical analyses. We considered a significant ecosystem by ${ }^{13} \mathrm{C}$ substrate interaction as evidence that microbial communities differed among tundra ecosystems in their ability to metabolize the labeled substrates. This interaction was additionally used to determine whether tracer-level addition of labeled substrates influenced rates of microbial respiration, $\mathrm{CH}_{4}$ production, and extracellular enzyme activity. Rates of microbial respiration, $\mathrm{CH}_{4}$ production, and extracellular enzyme activity were analyzed using the same approach. We also analyzed PLFA (mole \%) data using principal components analysis to ordinate sites within each tundra ecosystem, allowing us to visualize differences in microbial community composition. Significance for all statistical analyses was accepted at $\alpha=$ 0.05 .

\section{Results}

\section{Microbial community composition}

Microbial communities in tussock tundra, birchwillow, and wet sedge ecosystems differed significantly in composition, with soil fungi displaying a greater relative abundance in the tussock tundra than the other ecosystem types (Fig. 1). Of the 20 PLFAs used to assess microbial community composition, 14 displayed significant differences among the three tundra ecosystems (Fig. 1). For example, the relative abundance of fungal

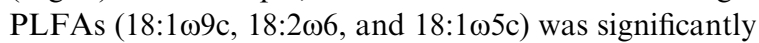
greater in tussock tundra, compared to the other ecosystems. This resulted in a significantly greater fungal:bacterial PLFA ratio in the tussock tundra (Table 1), suggesting that soil fungi were more abundant in this ecosystem. Regardless of this trend, our data clearly indicate that bacterial PLFAs surpassed fungal PLFAs, which is evident in the relatively low fungal:bacterial ratios in all three tundra ecosystems (Table 1).

Principal components analysis of PLFAs clearly distinguished microbial communities of the three tundra ecosystems (Fig. 2), each of which occupied very different ordination space. In this analysis, principal components axis (PCA) 1 and PCA 2 accounted for $79 \%$ of the variation among tundra ecosystems. Composite scores for replicate sites in the tussock and birch-willow ecosystems occupied the negative portion of PCA 1, on which fungal PLFAs (18:1 $15 \mathrm{c}, 18: 1 \omega 9 \mathrm{c}$, and 18:206; Fig. 2) received large negative weights $(-0.828$ to -1.000$)$; several bacterial PLFAs also received negative weights on this axis (i15:0, 


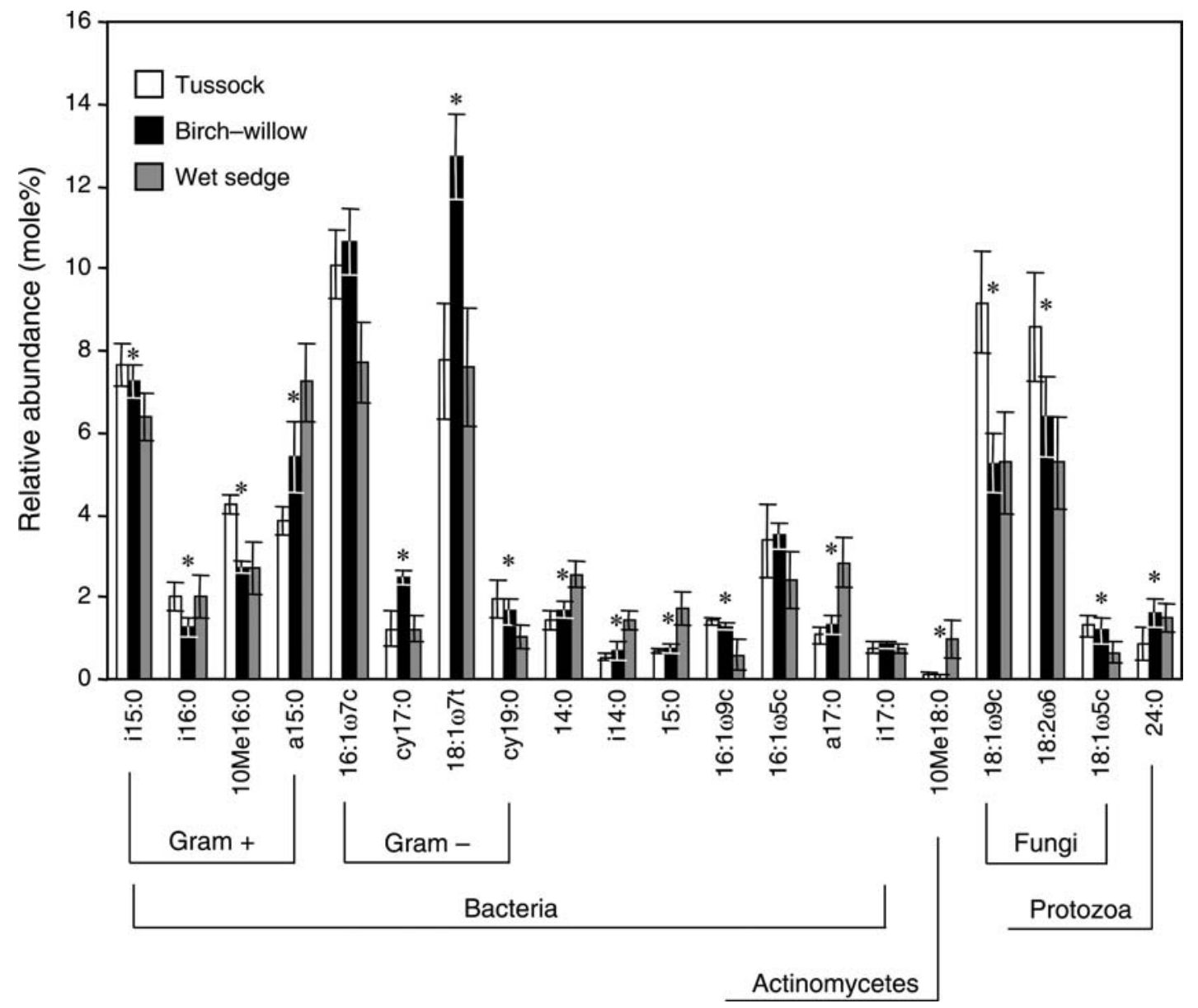

FIG. 1. Relative abundance of bacterial, actinomycetal, fungal, and protozoan PLFA in soil of three tundra ecosystems types in arctic Alaska, USA. We found no effect of ${ }^{13} \mathrm{C}$-substrate addition on the abundance of any PLFA. Values are ecosystem means $(n=$ 6; 2 sites $\times 3$ substrates $) \pm$ SE. Significant differences $(P<0.05)$ in the abundance of individual PLFAs among ecosystem types are indicated by asterisks.

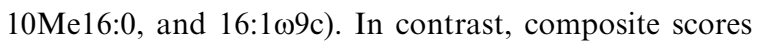
for the wet sedge sites resided on the positive portion of PCA 1, the result of the high positive weights (0.943$0.885)$ given to several bacterial PLFAs (14:0, i14:0, 15:0, a15:0, and a17:0; Fig. 2). On PCA 2, birch-willow sites were separated from the tussock and wet sedge sites due to high weights $(0.714-0.943)$ assigned to

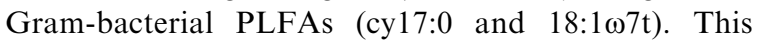

analysis clearly indicated that microbial communities were compositionally similar between sites within an ecosystem type, evidenced by the close grouping of replicate sites in ordination space (i.e., low withinecosystem variation; Fig. 2). This contrasts dramatically with the clear separation of microbial communities among the three different tundra ecosystems (i.e., among-ecosystem variation; Fig. 2).

TABLE 1. Rates of microbial respiration and methane production during a five-day incubation with ${ }^{13} \mathrm{C}$-labeled substrates, and the ratio of fungal to bacterial PLFA in soil of each tundra ecosystem type.

\begin{tabular}{|c|c|c|c|}
\hline Ecosystem & $\begin{array}{l}\text { Microbial respiration } \\
\left(\text { ng C } \cdot \mathrm{g}^{-1} \cdot \mathrm{h}^{-1}\right)\end{array}$ & $\begin{array}{l}\text { Net } \mathrm{CH}_{4} \text { production } \\
\left(\mathrm{pg} \mathrm{C} \cdot \mathrm{g}^{-1} \cdot \mathrm{h}^{-1}\right)\end{array}$ & $\begin{array}{l}\text { Fungal PLFA : } \\
\text { bacterial PLFA }\end{array}$ \\
\hline Tussock & $739^{\mathrm{a}}(54.9)$ & $56^{\mathrm{a}}(4.56)$ & $0.23^{\mathrm{a}}(0.011)$ \\
\hline Birch-willow & $778^{\mathrm{a}}(68.4)$ & $61^{\mathrm{a}}(6.3)$ & $0.14^{\mathrm{b}}(0.030)$ \\
\hline Wet sedge & $307^{\mathrm{b}}(28.1)$ & $434^{\mathrm{b}}(153.3)$ & $0.15^{\mathrm{b}}(0.015)$ \\
\hline
\end{tabular}

Notes: No significant effect of substrate addition was found on microbial respiration or methane production. Values are ecosystem means $(n=6 ; 2$ sites $\times 3$ substrates). Standard errors are in parentheses; means with different letters in a column are significantly different $(P<0.05)$. 


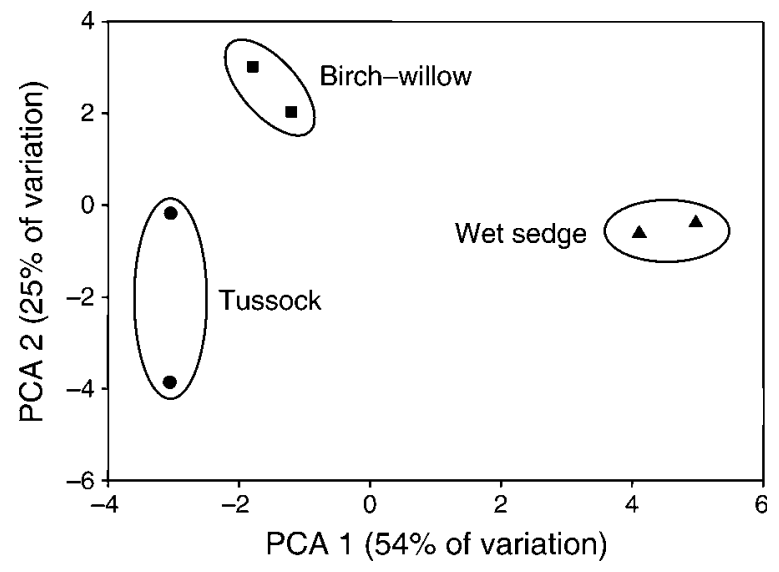

FIG. 2. Principal-components analysis using the relative abundance of individual PLFAs in three tundra ecosystems in arctic Alaska, USA. Soil microbial communities in the three ecosystems clearly occupy different portions of ordination space, indicating that microbial community composition differs substantially among the three tundra ecosystems. Individual points are replicate sites in each ecosystem type.

\section{Microbial respiration, net methane production, and extracellular enzyme activity}

Microbial respiration in the tussock and birch-willow ecosystems was over twice that in the poorly drained soil of the wet sedge; these differences were statistically significant (Table 1). In contrast, net $\mathrm{CH}_{4}$ production displayed the opposite trend, with the highest rates occurring in the anaerobic soil of the wet sedge ecosystem (434 $\left.\mathrm{pg} \mathrm{C} \cdot \mathrm{g}^{-1} \cdot \mathrm{h}^{-1}\right)$; rates in the tussock and birch-willow ecosystems were an order of magnitude lower (Table 1). The addition of ${ }^{13} \mathrm{C}$-labeled substrates had no effect on microbial respiration or $\mathrm{CH}_{4}$ production, indicating that the tracer-level additions of isotopically labeled substrates did not affect rates of microbial metabolism.

Extracellular enzyme analyses revealed significant differences in the potential for cellulose, chitin, and lignin degradation among tundra microbial communities. For example, rates of cellobiohydrolase activity were almost three times greater in the wet sedge compared to the tussock and birch-willow ecosystems (Fig. 3A). Similarly, $N$-acetylglucosaminidase activity in the wet sedge ecosystem was two times greater than in the other ecosystem types (Fig. 3C); these differences were statistically significant. Phenol oxidase and peroxidase displayed a different pattern, wherein rates in the birch-willow and wet sedge ecosystems were approximately two times greater than the rate in the tussock tundra (Fig. 3B and D). The significant differences we observed in microbial respiration, $\mathrm{CH}_{4}$ production, and extracellular enzyme activity indicate that microbial communities of these tundra ecosystems differ in function as well as in composition, as indicated by PLFA analysis.

\section{Microbial metabolism of ${ }^{13} \mathrm{C}$-labeled substrates}

Total recoveries of ${ }^{13} \mathrm{C}$-cellobiose $(93 \% \pm 6.3 \%),{ }^{13} \mathrm{C}$ $\mathrm{N}$-acetylglucosamine $(109 \% \pm 7.0 \%)$ and ${ }^{13} \mathrm{C}$-vanillin $(114 \% \pm 6.7 \%)$ did not significantly differ from $100 \%$, indicating that we could well account for movement of ${ }^{13} \mathrm{C}$-substrates among soil pools. Recovery of isotope was generally greater in soil organic $\mathrm{C}(\sim 75 \%)$ and microbial respiration $(\sim 25 \%)$, compared to amounts recovered in microbial biomass $(5 \%)$ and DOC (1\%).
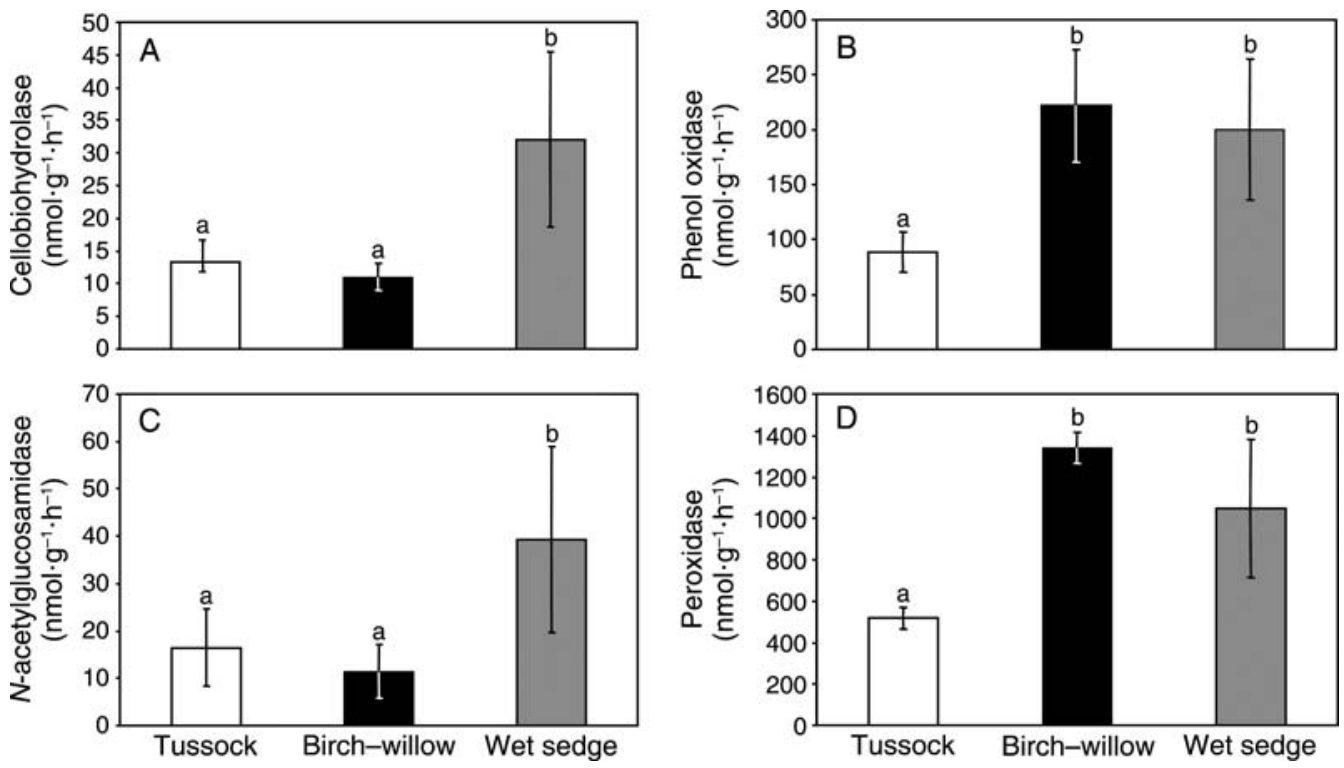

FIG. 3. Activity of extracellular enzymes involved in cellulose, chitin, and lignin degradation in soil of three tundra ecosystems. The enzyme assays depicted in this figure represent potential for the degradation of the aforementioned compounds. Values are ecosystem means \pm SE. The addition of ${ }^{13} \mathrm{C}$-labeled substrates had no effect on the activity of any enzyme summarized in this figure. 

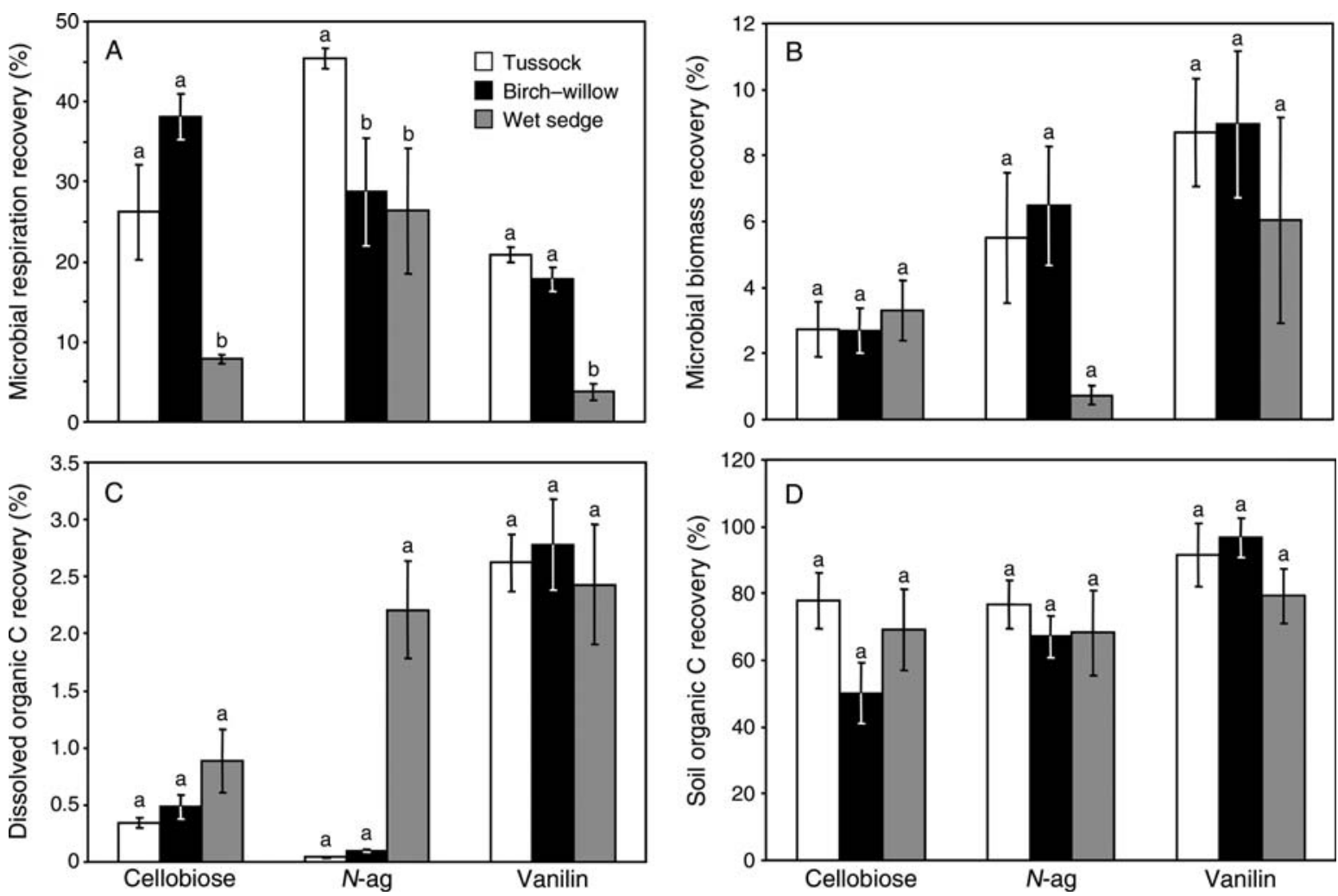

FIG. 4. Recovery of ${ }^{13} \mathrm{C}$-cellubiose, ${ }^{13} \mathrm{C}$ - $N$-acetylglucosamine, and ${ }^{13} \mathrm{C}$-vanillin in three tundra ecosystems in arctic Alaska, USA. Values are ecosystem means for the amount of applied label found in microbial respiration, microbial biomass, DOC, and soil organic matter. $N$-ag is $N$-acetylglucosamine.

The relatively low amounts recovered in DOC indicate that the majority of the original compounds were metabolized during our experiment.

Recovery of ${ }^{13} \mathrm{C}$ in microbial respiration was significantly influenced by an interaction between tundra ecosystem type and ${ }^{13} \mathrm{C}$-substrate, implying that microbial communities in these ecosystems differed in their ability to metabolize cellobiose, $N$-acetylglucosamine, and vanillin (Fig. 4A). For example, significantly lower amounts of ${ }^{13} \mathrm{C}$-cellobiose were respired by the microbial community in wet sedge (8\%), relative to amounts respired in the tussock $(26 \%)$ and birch-willow (38\%; Fig 4A). In contrast, almost twice as much ${ }^{13} \mathrm{C}-\mathrm{N}$ acetylglucosamine was respired in the tussock $(45 \%)$, compared to the other ecosystem types $(\sim 26 \%)$. Microbial respiration of ${ }^{13} \mathrm{C}$-vanillin was lowest in wet sedge $(\sim 5 \%)$, with approximately equivalent amounts respired in the tussock and birch-willow ( $\sim 18-21 \%$; Fig. 4A). Averaged across ecosystem type, microbial communities respired significantly lower amounts of ${ }^{13} \mathrm{C}$-vanillin $(14 \% \pm 2.3 \%)$ than ${ }^{13} \mathrm{C}$-cellobiose $(24 \% \pm 4.2 \%)$ or ${ }^{13} \mathrm{C}-N$-acetylglucosamine $(33 \pm 4.2 \%)$. Ecosystem type had a significant main effect on microbial respiration of ${ }^{13} \mathrm{C}$-substrates, wherein over twice as much ${ }^{13} \mathrm{C}$ was respired (averaged across ${ }^{13} \mathrm{C}$ substrate) in the tussock $(31 \% \pm 3.7 \%)$ and birch-willow $(28 \% \pm 3.3 \%)$ ecosystems compared to the wet sedge $(13 \% \pm 3.8 \%)$.
Recovery of ${ }^{13} \mathrm{C}$ in DOC represented a small fraction of the isotope we added $(\sim 1 \%)$, and recovery in this pool was not influenced by an interaction between ecosystem and ${ }^{13} \mathrm{C}$-substrate (Fig. 4C). Although ecosystem type was not a significant main effect in this analysis, the type of ${ }^{13} \mathrm{C}$-substrate added significantly influenced recovery in DOC. Recovery of ${ }^{13} \mathrm{C}$-vanillin $(3 \% \pm 0.2 \%)$ in DOC was significantly greater than the recovery of ${ }^{13} \mathrm{C}$ cellobiose or ${ }^{13} \mathrm{C}$ - $N$-acetylglucosamine $(\sim 0.5 \%)$ in this pool.

Soil organic C represented the largest pool of recovered ${ }^{13} \mathrm{C}$, regardless of ecosystem type or ${ }^{13} \mathrm{C}$ substrate (Fig. 4D). The interaction between ecosystem type and ${ }^{13} \mathrm{C}$-substrate did not have a significant effect on isotope recovery in soil organic C; ecosystem type also was not significant as a main effect. However, the type of ${ }^{13} \mathrm{C}$-substrate added (main effect) significantly influenced ${ }^{13} \mathrm{C}$ recovery in soil organic $\mathrm{C}$, wherein significantly more ${ }^{13} \mathrm{C}$-vanillin $(89 \% \pm 4.7 \%)$ was recovered in this pool than ${ }^{13} \mathrm{C}-\mathrm{N}$-acetylglucosamine $(71 \% \pm 6.9 \%)$ or ${ }^{13} \mathrm{C}$-cellobiose $(66 \% \pm 6.2 \%)$.

We found no significant interaction between ecosystem type and ${ }^{13} \mathrm{C}$-substrate on the recovery of ${ }^{13} \mathrm{C}$ in microbial biomass (i.e., total PLFA; Fig. 4B), nor did ecosystem type exert a significant main effect on recovery in this pool (data not shown). However, the type of ${ }^{13} \mathrm{C}$-substrate added (main effect) significantly 

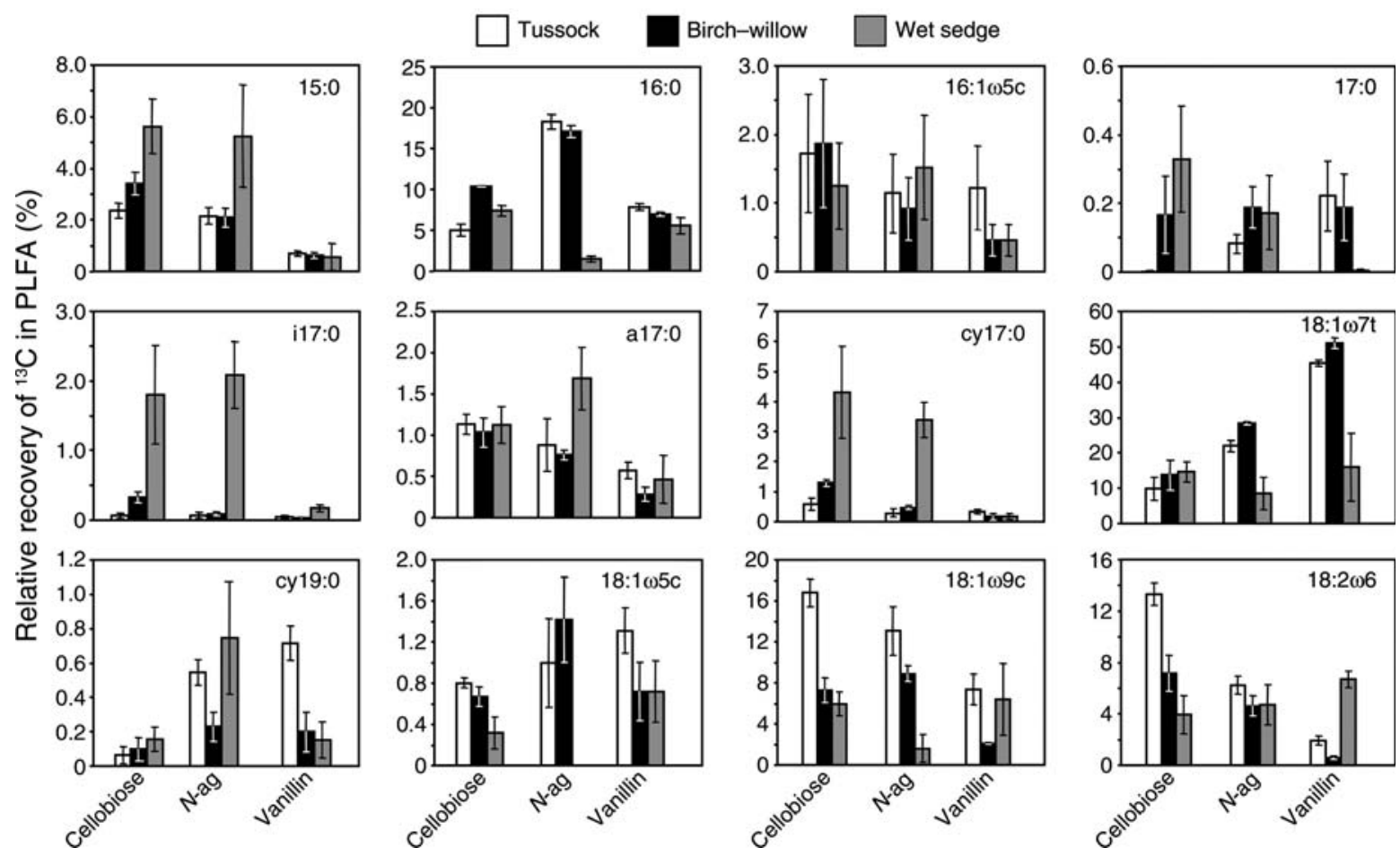

FIG. 5. Relative recovery of ${ }^{13} \mathrm{C}$-labeled substrates (i.e., $\left[\left({ }^{13} \mathrm{C}\right.\right.$ in individual PLFA) $/\left({ }^{13} \mathrm{C}\right.$ in total PLFA) $\left.] \times 100\right)$ in individual PLFAs extracted from the soil of three tundra ecosystems in arctic Alaska, USA. Depicted in this figure are PLFAs for which we found a significant interaction between ecosystem type and ${ }^{13} \mathrm{C}$-labeled compound. Values are interaction means $\pm \operatorname{SE}(n=2) . N$-ag is $N$-acetylglucosamine.

influenced recovery of ${ }^{13} \mathrm{C}$ in microbial biomass, with the greatest amounts of ${ }^{13} \mathrm{C}$-vanillin $(8 \% \pm 1.3 \%)$ recovered in microbial biomass followed by ${ }^{13} \mathrm{C}-\mathrm{N}$ acetylglucosamine $(4 \% \pm 1.1 \%)$ and ${ }^{13} \mathrm{C}$-cellobiose $(3 \%$ $\pm 0.4 \%)$. We assessed the relative recovery of ${ }^{13} \mathrm{C}$ in individual PLFAs to determine if different microbial groups were responsible for the degradation of ${ }^{13} \mathrm{C}$ substrates among tundra ecosystems (Fig. 5). Regardless

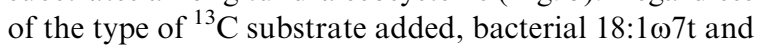
fungal $18: 1 \omega 9 \mathrm{c}$ contained the largest relative amount of ${ }^{13} \mathrm{C}$ recovered in PLFA (Fig. 5). Among several bacterial

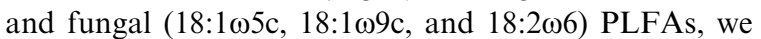
observed a significant interaction between ecosystem type and ${ }^{13} \mathrm{C}$ substrate. In general, fungal PLFAs

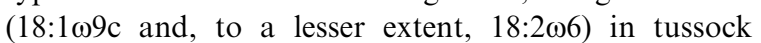
tundra contained relatively greater amounts of ${ }^{13} \mathrm{C}$ substrates than in the other two ecosystem types. The largest relative amount (percentage of ${ }^{13} \mathrm{C}$ in total PLFA) of ${ }^{13} \mathrm{C}$-vanillin was recovered in bacterial 18:107t in the tussock and birch-willow ecosystems; a much smaller amount was recovered in wet sedge.

We calculated the ratio of ${ }^{13} \mathrm{C}$ recovered in fungal versus bacterial PLFAs to better understand the importance of these organisms in metabolizing ${ }^{13} \mathrm{C}$ substrates among tundra ecosystems. The ratio of ${ }^{13} \mathrm{C}$ cellobiose recovered in fungal vs. bacterial PLFA was $\sim 0.99 \pm 0.13$ in tussock tundra, indicating equivalent metabolism of this substrate by fungi and bacteria.
However, soil bacteria became more important in the metabolism of ${ }^{13} \mathrm{C}$-cellobiose in the birch-willow and wet sedge, in which the ratios of ${ }^{13} \mathrm{C}$ in fungal to bacterial PLFAs fell to $0.34 \pm 0.09$ and $0.16 \pm 0.09$, respectively. Soil bacteria were clearly dominating the metabolism of ${ }^{13} \mathrm{C}-N$-acetylglucosamine, evidenced by relatively low ratios of ${ }^{13} \mathrm{C}$ in fungal vs. bacterial PLFA in the tussock $(0.30 \pm 0.06)$, birch-willow $(0.21 \pm 0.04)$, and wet sedge $(0.15 \pm 0.06)$ ecosystems. Soil fungi were relatively unimportant in the metabolism of vanillin, with very low ratios of ${ }^{13} \mathrm{C}$ in fungal vs. bacterial PLFA in the tussock $(0.09 \pm 0.02)$ and birch-willow $(0.02 \pm$ $0.00)$. Values in the wet sedge were somewhat higher $(0.23 \pm 0.12)$, but still indicate that soil bacteria were the primary degraders of ${ }^{13} \mathrm{C}$ vanillin in these tundra soils.

\section{DisCUSSION}

Arctic ecosystems differ dramatically in plant community composition, litter biochemistry, and rates of biogeochemical processes across relatively short distances ( 100-200 m; Giblin et al. 1991, Nadelhoffer et al. 1991, Shaver and Chapin 1991). These ecological differences are paralleled by physical gradients of soil drainage and the seasonal thaw depth of frozen soil. Because soil microbial communities are, in part, structured by organic substrates in plant litter, we reasoned that the composition and function of soil microbial communities should parallel changes in plant 
community composition. That is, floristically distinct tundra ecosystems, which differ in litter biochemistry and occupy contrasting landscape positions, should contain compositionally and functionally distinct microbial communities beneath them. Our results collectively support the idea that plant and microbial communities are associated across the arctic landscape and that distinct microbial communities reside beneath floristically and biogeochemically distinct tundra ecosystems. Microbial respiration of ${ }^{13} \mathrm{C}$-substrates indicate that microbial communities in tussock tundra and birchwillow have a greater capacity to metabolize labile substrates compared to wet sedge tundra, especially the products of cellulose degradation. This difference in metabolic capacity is consistent with the observed increase in the proportion of soluble phenolics as DOC moves from upland to aquatic ecosystems across the arctic landscape (Judd and Kling 2002).

Microbial communities beneath the three tundra ecosystems differed from one another in composition and function, a spatial pattern that likely resulted from differences in litter inputs as well as the soil environment. For example, soil fungi were relatively more abundant and metabolically active in the tussock tundra than in the other ecosystem types. Evidence for this assertion comes from the greater relative abundance of fungal PLFAs in tussock tundra as well as greater recovery of ${ }^{13} \mathrm{C}$ in fungal PLFAs. In addition, the fact that the fungal:bacterial ratio of PLFAs was 0.23 in tussock tundra, and yet there was a $\sim 1: 1$ rate of incorporation of ${ }^{13} \mathrm{C}$-cellobiose into total fungal and bacterial PLFAs, indicates that the fungi are more active processors of the substrates we added than would be assumed given their biomass alone. Similarly, in the birch-willow and wet sedge ecosystems, cellobiose and $N$-acetylglucosamine metabolism (indicated by the ${ }^{13} \mathrm{C}$ distributions) by fungi were up to two times greater than one would expect given their biomass vs. the bacterial biomass. For example, the fungal: bacterial ratio of PLFA in the birch-willow was only 0.14 , but the fungal : bacterial ratios of ${ }^{13} \mathrm{C}$ incorporation for cellobiose and $N$-acetylglucosamine were 0.30 and 0.21 , respectively.

Although the fungi appear to be more important in $\mathrm{C}$ processing than their biomass would indicate, they may be limited in distribution among tundra ecosystems by the degree to which anaerobic conditions persist across the landscape. Wet sedge tundra lies downslope from the other ecosystem types, and it occupies landscape positions that gather subsurface water flow; this situation occurs to a lesser extent in the birch-willow tundra (Shaver and Chapin 1991, Giblin et al. 1991). With few exceptions, filamentous soil fungi are obligate aerobes (Alexander 1976), and it is likely that anaerobic conditions in the birch-willow and wet sedge soils restrict fungal abundance and overall activity. Tussock tundra soils also are periodically saturated, but their upland landscape position allows them to freely drain, which creates aerobic conditions amenable for fungal activity. Although our study was not designed to separate causal factors structuring soil microbial communities (i.e., plant litter biochemistry vs. soil environment), the abundance of soil fungi across this landscape may be constrained more by environmental conditions than by differences in organic substrates produced by plant communities.

The aforementioned situation is exemplified by substantial net methane production in the wet sedge soil, relative to that in tussock and birch-willow tundra (Table 1; Whalen and Reeburgh 1988, 1990, Schimel 1995). At the time of study, soils of the wet sedge tundra had several centimeters of standing water above their surface, which undoubtedly exerted a substantial influence on microbial activity in the field. To simulate this condition, we incubated soil from wet sedge tundra in an anaerobic atmosphere; soils from the other ecosystems were incubated in the ambient atmosphere. High rates of net methane production in the wet sedge tundra resulted from the conditions of our laboratory experiment, which were clearly similar to those occurring in the field. Methanogenesis is a bacterial process, and bacteria clearly dominated the microbial community of the wet sedge tundra, both in abundance and overall activity. This is evident by the relatively low ratio of fungal to bacterial PLFAs, in addition to the fact that bacterial PLFAs in wet sedge soil contained more ${ }^{13} \mathrm{C}$ than fungal PLFAs, regardless of the ${ }^{13} \mathrm{C}$ tracer applied. Thus, parallel gradients in plant community composition and soil drainage work in concert to control the composition and function of microbial communities across this landscape.

Given the low temperature $\left(2.8^{\circ} \mathrm{C}\right)$ of our experiment, surprisingly large amounts of ${ }^{13} \mathrm{C}$-labeled substrates were metabolized by microbial communities in the three tundra ecosystems. For example, $20-45 \%$ of ${ }^{13} \mathrm{C}$ cellobiose was respired over our five-day experiment. Adjusting for differences in the length of incubation, these amounts are comparable to those respired by microbial communities in temperate forest soils incubated at $20^{\circ} \mathrm{C}(20-58 \%$; sensu DeForest et al. 2004, Waldrop et al. 2004). In these same forests, microbial communities respired $20-40 \%$ of ${ }^{13} \mathrm{C}$-vanillin, whereas $\sim 20 \%$ of this compound was respired in the tussock and birch-willow soils; amounts respired were lower in wet sedge tundra (Fig. 4A). The most striking difference between forest and tundra soils occurs in the proportion of these compounds forming soil organic matter, wherein $8-20 \%$ of ${ }^{13} \mathrm{C}$-cellobiose entered soil organic matter in forests vs. $50-79 \%$ in tundra ecosystems; this disparity was less for ${ }^{13} \mathrm{C}$-vanillin (50-72\% in forests vs. $80-98 \%$ in tundra). Clearly, soil organic matter is formed from these compounds at a much greater rate in tundra soil, even at the low temperatures of our study. We are unaware of other studies following the microbial metabolism of ${ }^{13} \mathrm{C}$ - $\mathrm{N}$-acetylglucosamine in unmanaged ecosystems, thus limiting our ability to make compar- 
isons. Regardless of the large temperature differences $\left(2.8^{\circ}\right.$ vs. $\left.20.0^{\circ} \mathrm{C}\right)$, microbial communities in the tundra ecosystems metabolized cellobiose and vanillin to an equivalent or greater extent than those in temperate ecosystems. These observations support previous observations that microbial communities in tundra soil attain high rates of metabolism at relatively cold soil temperatures, even sustaining some metabolic activity when soils are completely frozen (Fahnestock et al. 1998, 1999, Jones et al. 1999, Welker et al. 2000).

Several lines of evidence suggest that microbial communities of the three tundra ecosystems differ in their capacity to metabolize plant and fungal cell walls. For example, microbial respiration of ${ }^{13} \mathrm{C}$-labeled compounds representative of cell wall constituents varied in an ecosystem-specific manner, indicating that microbial communities of the tussock, birch-willow, and wet sedge tundra differed in their ability to metabolize cellobiose, $N$-acetylglucosamine, and vanillin. Moreover, it appears that the flow of substrates through the soil microbial food web also differs among tundra ecosystems. Evidence for this contention comes from differences among the three ecosystems in the extent to which fungal and bacterial PLFAs became enriched after the addition of ${ }^{13} \mathrm{C}$-cellobiose, ${ }^{13} \mathrm{C}-\mathrm{N}$-acetylglucosamine, and ${ }^{13} \mathrm{C}$-vanillin (Fig. 5). The aforementioned physiological differences paralleled distinct differences in microbial community composition among ecosystems, as measured by PLFA analysis. In combination, our results indicate that microbial community composition and function varied in concert across the arctic landscape in a manner that was consistent with documented changes in plant community composition, conditions of soil drainage, and rates of biogeochemical processes (Giblin et al. 1991, Nadelhoffer et al. 1991).

Patterns of extracellular enzymatic activity among the three tundra ecosystems did not correspond with our initial expectations (Fig. 3). For example, extracellular enzyme activity was generally greatest in the wet sedge tundra and lowest in the better-drained tussock tundra soil; we expected to observe the opposite. This disparity was particularly evident for phenol oxidase activity, which more than doubled from the tussock to wet sedge tundra (Fig. 3B). Filamentous Basidiomycota are the primary agents of lignin degradation in soil, they are obligate aerobes, and we expected that the anaerobic conditions in wet sedge tundra would preclude these organisms. This is consistent with our observation of low fungal abundance in wet sedge soil (i.e., low fungal to bacterial PLFA ratio), but it does not explain high rates of phenol oxidase activity in the saturated soil of the wet sedge tundra. Recent evidence confirms that phenol oxidase genes reside in the genome of Bacillis subtilis (Hullo et al. 2001) as well as the actinomycete, Streptomyces griseus (Endo et al. 2003). It also is well known that several genera of soil actinomycetes have lignolytic capability (Crawford 1978, Mason et al. 1988), and actinomycete abundance, as measured by 10Me18:0, was greatest in wet sedge tundra. Thus, the bacterial dominance we document in the wet sedge tundra, in combination with the aforementioned observations, suggests that soil bacteria and actinomycetes together may be responsible for relatively high phenol oxidase activity in wet sedge tundra (Fig. 3B; see Judd 2004).

Although it is plausible that soil bacteria and actinomycetes are agents of polyphenol oxidation in wet sedge tundra, phenol oxidase requires $\mathrm{O}_{2}$ for catalytic activity, and anaerobic conditions would clearly prevent this enzyme from functioning, even if it was produced by these organisms. If their functioning was prevented, then, what factors gave rise to high potential rates of phenol oxidase and peroxidase in the anaerobic soil of wet sedge tundra? This observation may be reconciled by the presence of aerenchyma in Carex aquatilis, the dominant plant in this ecosystem (Chapin et al. 1980). These conductive tissues supply Carex roots with $\mathrm{O}_{2}$ which can diffuse radially into the rhizosphere (Visser et al. 2000), thereby creating conditions favorable for phenol oxidase function. Wet sedge surface soil is permeated by a high density of Carex roots, which display an accumulation of iron oxide on their surface (D. Zak and G. Kling, personal observation). This observation is consistent with radial $\mathrm{O}_{2}$ loss into the rhizosphere, which, in turn, could produce higher-thanexpected rates of polyphenol oxidation in wet sedge tundra. Thus, aerobic microsites for polyphenol oxidation in the rhizosphere could exist in an anaerobic soil matrix in which net methane production occurred (Table 1). Alternatively, our assays represent a potential for enzymatic activity, which may not be realized in the field for many reasons; relatively low rates of ${ }^{13} \mathrm{C}$-vanillin metabolism suggest this could be the case for phenol oxidase and peroxidase in wet sedge tundra. The aforementioned mechanisms for polyphenol oxidation in wet sedge tundra would clearly require experimental confirmation, and we can only speculate on their operation under field conditions. Nonetheless, given appropriate conditions (e.g., aeration), there appears to be a high potential for polyphenol oxidation in wet sedge soil, at least in well-aerated microsites or during unusually dry periods.

Differences in plant biochemistry among tundra ecosystems, in combination with the microbial metabolism of organic substrates, may help explain the accumulation of phenolics as DOC moves downslope from tussock to wet sedge tundra. Dominant plants in tussock and birch-willow tundra contain higher lignin concentrations (15-34\%) than those dominating wet sedge tundra ( $\sim 6 \%$ ) (Hobbie 1996, Robinson et al. 1999, Larter and Nagy 2001); the same is true for soluble phenolics. This pattern of plant tissue biochemistry opposes that of phenolics in DOC, which increase from tussock to wet sedge tundra (Michelson et al. 1998). These contrasting patterns suggest that the high phenolic content of wet sedge DOC results from the downslope accumulation of phenolics, which originate 
from upslope ecosystems. Even though extracellular enzyme activities were generally low in tussock tundra, microbial respiration of ${ }^{13} \mathrm{C}$-cellobiose (as well as ${ }^{13} \mathrm{C}-\mathrm{N}$ acetylglucosamine) was generally high. If this occurs consistently in the field, it suggests that cellulose metabolism proceeds more rapidly in tussock and birch-willow tundra than in wet sedge tundra, which contrasts with much lower rates of ${ }^{13} \mathrm{C}$-vanillin metabolism in all of these tundra ecosystems. In combination with high concentrations of lignin in plant tissue, these microbial processes may function to increase the phenolic content of DOC as it moves downslope toward wet sedge tundra. It remains to be determined exactly how the production of lignin, the decomposition of phenols, and the associated microbial processing all interact to produce the patterns of DOM chemistry observed on the landscape.

In conclusion, our results demonstrate that microbial community composition and function displays a repeatable pattern across the arctic landscape, which coincides with changes in plant community composition, tissue biochemistry, soil drainage, and rates of biogeochemical processes. The patterns of microbial community composition and function we observed appear to be structured by gradients of plant litter biochemistry as well as environmental conditions resulting from topography and soil drainage, but the relative importance of these factors in structuring these microbial communities remains to be determined. Our results imply that differences in the metabolic capacity of microbial communities among tundra ecosystems influence landscape-level transformations of DOC, such as observed increases in phenolic content as this material moves down slope. In combination, our observations support the idea that distinct microbial communities reside beneath floristically and biogeochemically distinct ecosystems, and that corresponding differences in microbial community function have implications for the processing of DOC across the arctic landscape.

\section{ACKNOWLedgments}

Our research was supported by grants from the NSF Office of Polar Programs (OPP-0408371) and by the NSF Long-Term Ecological Research Program (DEB-0423385). We gratefully acknowledge Bill Holmes and Jana Gastellum for their work on PLFA and stable isotope analyses of these tundra soils. We also thank Knute Nadelhoffer, whose comments substantially contributed to this work.

\section{Literature Cited}

Alexander, M. 1976. Introduction to soil microbiology. Second edition. John Wiley and Sons, New York, New York, USA.

Britton, M. E. 1966. Vegetation of the arctic tundra. Pages 67130 in H. P. Hanson, editor. Arctic biology. Oregon State University Press, Corvallis, Oregon, USA.

Chapin, F. S., III, and G. R. Shaver. 1985. The physiological ecology of arctic plants. Pages 16-40 in B. Chabot and H. A. Mooney, editors. Physiological ecology of North American plants. Chapman and Hall, London, UK.

Chapin, F. S., III, L. L. Tieszen, M. C. Lewis, P. C. Miller, and B. H. McCown. 1980. Control of tundra plant allocation patterns and growth. Pages 140-185 in J. Brown, P. C. Miller,
L. L. Tieszen, and F. L. Bunnel, editors. An arctic ecosystem: the coastal tundra at Barrow, Alaska. Dowden, Hutchinson and Ross, Stroudsburg, Pennsylvania, USA.

Cheng, W. X., R. A. Virginia, S. F. Oberbauer, C. T. Gillespie, J. F. Reynolds, and J. D. Tenhunen. 1998. Soil nitrogen, microbial biomass, and respiration along an Arctic toposequence. Soil Science Society of America Journal 62:654662.

Crawford, D. L. 1978. Lignocellulose decomposition by selected Streptomyces strains. Applied Environmental Microbiology 35:1041-1045.

DeForest, J. L., D. R. Zak, K. S. Pregitzer, and A. J. Burton. 2004. Nitrate deposition and the microbial degradation of cellulose and lignin in a northern hardwood forest. Soil Biology and Biochemistry 36:965-971.

Endo, E., Y. Hayashi, T. Hibi, K. Honsono, T. Beppu, and K. Ueda. 2003. Enzymological characterization of EpoA, a laccase-like phenol oxidase produced by Streptomyces griseus. Journal of Biochemistry 133:671-677.

Fahnestock, J. T., M. H. Jones, P. D. Brooks, D. A. Walker, and J. M. Welker. 1998. Winter and spring $\mathrm{CO}_{2}$ efflux from tundra communities of Northern Alaska. Journal of Geophysical Research 103:29023-29027.

Fahnestock, J. T., M. H. Jones, and J. M. Welker. 1999. Wintertime $\mathrm{CO}_{2}$ efflux from arctic soils: implications for annual carbon budgets. Global Biogeochemical Cycles 13: $775-779$.

Giblin, A. E., K. J. Nadelhoffer, G. R. Shaver, J. A. Laundre, and A. J. McKerrow. 1991. Biogeochemical diversity along a river toposequence in arctic Alaska. Ecological Monographs 61:415-435.

Hobbie, S. E. 1996. Temperature and plant species control over litter decomposition in Alaskan tundra. Ecological Monographs 66:503-522.

Hullo, M. F., I. Moszer, A. Danchin, and I. Martin-Verstraete. 2001. CotA of Bacillus subtilis is a copper-dependent laccase. Journal of Bacteriology 183:5426-5430.

Jones, M. H., J. T. Fahnestock, and J. M. Welker. 1999. Early and late winter $\mathrm{CO}_{2}$ efflux from arctic tundra in the Kuparuk River watershed, Alaska, USA. Arctic and Alpine Research 31:187-190.

Judd, K. E. 2004. Dissolved organic matter dynamics in an arctic catchment: linking DOM chemistry, bioavailability, and microbial community composition. Dissertation. University of Michigan, Ann Arbor, Michigan, USA.

Judd, K. E., and G. W. Kling. 2002. Production and export of dissolved $\mathrm{C}$ in arctic tundra mesocosms: the roles of vegetation and water flow. Biogeochemistry 60:213-234.

Kling, G. W., G. W. Kipphut, M. C. Miller, and W. J. O'Brien. 2000. Integration of lakes and streams in a landscape perspective: the importance of material processing on spatial patterns and temporal coherence. Freshwater Biology 43: $477-497$.

Larter, N. C., and J. A. Nagy. 2001. Seasonal and annual variability in the quality of important forage plants on Banks Island, Canadian High Arctic. Applied Vegetation Science 4: $115-128$.

Lipson, D. A., C. W. Schadt, and S. K. Schmidt. 2002. Changes in soil microbial community structure and function in an alpine dry meadow following spring snow melt. Microbial Ecology 43:307-314.

Lipson, D. A., S. K. Schmidt, and R. D. Monson. 1999. Links between microbial population dynamics and plant $\mathrm{N}$ availability in an alpine ecosystem. Ecology 80:1623-1631.

Martins, L. O., C. M. Soares, M. M. Pereira, M. Teixeira, T. Costa, G. H. Jones, and A. O. Henriques. 2002. Molecular and biochemical characterization of a highly stable bacterial laccase that occurs as a structural component of the Bacillus subtilis endospore coat. Journal of Biological Chemistry 277: 18849-18859. 
Mason, J. C., M. Richards, W. Zimmermann, and P. Broda 1988. Identification of extracellular proteins from actinomycetes responsible for the solubilization of lignocellulose. Applied Microbiology and Biotechnology 28:276-280.

McCulley, R. L., and I. C. Burke. 2004. Microbial community composition across the Great Plains: Landscape versus regional variability. Soil Science Society of America Journal 68:106-115.

Michaelson, G. L., C. L. Ping, G. W. Kling, and J. E. Hobbie. 1998. The character and bioactivity of dissolved organic matter at thaw and in spring runoff waters of the arctic tundra north slope, Alaska. Journal of Geophysical Research-Atmospheres 103:28939-28946.

Myers, R. T., D. R. Zak, D. C. White, and A. Peacock. 2001. Landscape-level patterns of microbial community composition and substrate use in upland forest ecosystems. Soil Science Society of America Journal 65:359-367.

Nadelhoffer, K. J., A. E. Giblin, G. R. Shaver, and J. Laundre. 1991. Effects of temperature and organic matter quality on element mineralization in six arctic soils. Ecology 72:242253.

Nadelhoffer, K. J., L. Johnson, J. Laundre, A. E. Giblin, and G. R. Shaver. 2002. Fine root production and nutrient content in wet and moist arctic tundras as influenced by chronic fertilization. Plant and Soil 242:107-113.

Neff, J. D., and D. U. Hooper. 2002. Vegetation and climate controls on potential $\mathrm{CO}_{2}$, DOC and DON production in northern latitude soils. Global Change Biology 8:872-884.

Phillips, R. L., D. R. Zak, W. E. Holmes, and D. C. White. 2002. Microbial community composition and function beneath temperate trees exposed to elevated atmospheric $\mathrm{CO}_{2}$ and $\mathrm{O}_{3}$. Oecologia 131:236-244.

Robinson, C. H., J. B. Kirkham, and R. Littlewood. 1999. Decomposition of root mixtures from high arctic plants: a mesocosm study. Soil Biology and Biochemistry 31:11011108 .

Schadt, C. W., A. P. Martin, D. A. Lipson, and S. K. Schimdt. 2003. Seasonal dynamics of previously unknown fungal lineages in tundra soil. Science 301:1359-1361.
Schimel, J. P. 1995. Plant transport and methane production as controls on methane flux from arctic wet meadow tundra. Biogeochemistry 28:183-200.

Shaver, G. R., and F. S. Chapin, III. 1991. Production: biomass relationships and elemental cycling in contrasting arctic vegetation types. Ecological Monogographs 61:1-31.

Shaver, G. R., K. J. Nadelhoffer, and A. E. Giblin. 1991. Biogeochemical diversity and element transport in a heterogeneous landscape, the North Slope of Alaska. Pages 105126 in M. G. Turner and R. H. Gardner, editors. Quantitative methods in landscape ecology. Springer-Verlag, New York, New York, USA

Stevenson, B. A., G. P. Sparling, L. A. Schipper, B. P. Degens, and L. C. Duncan. 2004. Pasture and forest soil microbial communities show distinct pattern in their catabolic respiration responses at a landscape scale. Soil Biology and Biochemistry 36:49-55.

St-Jean, G. 2003. Automated quantitative and isotopic $\left({ }^{13} \mathrm{C}\right)$ analysis of dissolved inorganic carbon and dissolved organic carbon in continuous-flow using a total organic carbon analyser. Rapid Communications in Mass Spectrometry 17: 419-428.

Visser, E. J., T. D. Colmer, W. P. M. Blom, and C. J. Voesenek. 2000 . Changes in the growth, porosity, and radial oxygen loss from adventitious roots of selected mono- and dicotyledonous wetland species with contrasting types of aerenchyma. Plant Cell and Environment 23:1237-1245.

Waldrop, M. P., D. R. Zak, and R. L. Sinsabaugh. 2004. Microbial community response to nitrogen deposition in northern forest ecosystems. Soil Biology and Biochemistry 36:1443-1451

Welker, J. M., J. T. Fahnestock, and M. H. Jones. 2000. Annual $\mathrm{CO}_{2}$ flux in dry and moist arctic tundra: field responses to increases in summer temperatures and winter snow depth. Climatic Change 44:139-150.

Whalen, S. C., and W. S. Reeburgh. 1990. A methane flux transect along the trans-Alaska pipeline haul road. Tellus 42B: $237-249$

White, D. C., W. M. Davis, J. S. Nickels, J. D. King, and R. J. Bobbie. 1979. Determination of the sedimentary microbial biomass by extractable lipid phosphate. Oecologia 40:51-62. 